\title{
PENGEMBANGAN BAHAN AJAR TEORI BILANGAN BERBASIS MACROMEDIA FLASH
}

\author{
Ulum Fatmahanik \\ Fakultas Tarbiyah, Institut Agama Islam Negeri Ponorogo, Indonesia \\ ulum.fatma@gmail.com
}

\begin{abstract}
Abstrak: Penelitian ini bertujuan untuk menghasilkan dan mengetahui kualitas bahan ajar teori bilangan berbasis Macromedia Flash serta untuk mengetahui respon mahasiswa terhadap bahan ajar yang telah dikembangkan. Bahan ajar ini disusun menggunakan program Macromedia Flash Professional 8. Model pengembangan dalam penelitian ini menggunakan model ADDIE (Analysis, Design, Development, Implementation and Evaluation) dalam menghasilkan produk. Hasil penilaian ahli materi menunjukkan bahwa bahan ajar teori bilangan berbasis Macromedia Flash yang telah dikembangkan mempunyai kualitas baik dengan diperoleh skor $80,63 \%$. Sedangkan hasil penilaian ahli media menunjukkan bahwa bahan ajar teori bilangan berbasis Macromedia Flash mempunyai kualitas baik dengan diperoleh skor $84,17 \%$. Sedangkan respon mahasiswa $52 \%$ menyatakan baik dan 40,06\% mahasiswa menatakan sangat baik. Berdasarkan penilaian tersebut berarti bahan ajar teori bilangan berbasis Macromedia Flash layak digunakan sebagai sumber belajar mandiri dalam pembeljaran teori bilangan.
\end{abstract}

Katakunci: Bahan Ajar; Macromedia Flash; Teori Bilangan.

\begin{abstract}
This study aims to produce and determine the quality of number theory teaching materials based on macromedia flash and to determine student responses to the teaching materials that have been developed. This teaching material is prepared using the Macromedia Flash Professional 8 program. The development model in this study uses the ADDIE (Analysis, Design, Development, Implementation and Evaluation) model in producing products. The results of the material expert's assessment showed that the macromedia flash-based number theory teaching materials that had been developed had good quality with a score of $80.63 \%$. Meanwhile, the results of the media expert's assessment showed that number theory teaching materials based on Macromedia Flash had good quality with a score of $84.17 \%$. Meanwhile, $52 \%$ student response said it was good and $40.06 \%$ of students said it was very good. Based on this assessment, it means that number theory teaching materials based on macromedia flash are suitable for use as an independent learning resource in learning number theory.
\end{abstract}

Keywords: Teaching Materials; Macromedia Flash; Number Theory.

\section{Pendahuluan}

Mata kuliah teori bilangan merupakan salah satu mata kuliah yang dianggap bagi mahasiswa PGMI di IAIN Ponorogo. Padahal mata kuliah ini merupakan mata kuliah yang wajib ditempuh oleh mahasiswa Pendidikan Guru MI di IAIN Ponorogo saat memilih konsentrasi matematika pada semester 5. Mata kuliah teori bilangan dirancang untuk membekali mahasiswa PGMI agar setelah mengikuti mata kuliah ini mahasiswa mampu menguasai konsep teori bilangan, yang ditunjukkan dengan kemampuan bekerja dalam menerapkan konsep-konsep sistem bilangan bulat dan sifat-sifatnya, operasi dalam sistem matematika, sifat-sifat operasi biner, sistem bilangan bulat, notasi sigma dan induksi matematika, teorema binomial, pembagian (habis dibagi, FPB, KPK), 
Algoritma U-clides dan kombinasi linier serta konsep dasar kongruensi.

Berdasarkan hasil pengalaman dosen pengampu selama mengajar ternyata ada keterbatasan dan kesulitan referensi berbahasa Indonesia dari mata kuliah ini, kebanyakan referensi berbahasa Inggris. Selain itu dalam proses pembelajarannya masih belum bisa efektif dan menyebabkan hasil belajar teori bilangan tergolong relatif rendah. Hal itu ditunjukkan dengan skor hasil belajar UTS sekitar $45,67 \%$ yang mencapai ketunasan dan 54,33\% masih di bawah rata-rata. Inilah yang memotivasi dosen pengampu mata kuliah ini untuk menyusun bahan ajar mata kuliah teori bilangan. Hal ini sesuai dengan pernyataan Ramdani (Shodikin, 2017, pp. 1-11) bahwa bahan ajar yang digunakan dalam proses pembelajaran bisa menjadi penyebab dan alasan rendahnya hasil belajar peserta didik.

Oleh karena itu diperlukan bahan ajar yang relevan sehingga tujuan pembelajaran dapat tercapai. Bahan ajar bisa dalam bentuk bahan ajar tertulis maupun tidak tertulis (Amri \& Ahmadi, 2010, p. 159) sehingga dalam pengembangannya yang paling penting adalah kesesuaian dengan karakter pesera didik itu sendiri. Jika hal ini tidak diperhatikan, bahan ajar dapat menghambat proses pembelajaran itu sendiri (Uzuegbu et al., 2013, pp. 111120).

Selain itu, bahan ajar dapat meningkatkan kemampuan yang bersifat umum dalam bentuk hasil belajar (Iji et al., 2014, pp. 504-509) dan juga dapat meningkatkan kemampuan kognitif peserta didik (Nwike \& Catherine, 2013, pp. 43-51). Eskey \& Grabe menyatakan bahwa bahan ajar dapat meningkatkan kemampuan kognitif siswa berdasarkan tingkatan kemampuan seperti membaca dan memahami (Dubin et al., 1986) serta representasi (Mahardika, 2011) dan melatih berpikir kritis (Zakiyah, 2012).

Bahan ajar merupakan segala bentuk bahan yang digunakan untuk membantu guru maupun instruktur dalam melaksanakan kegiatan belajar mengajar di kelas, bisa berbentuk bahan ajar tertulis maupun tidak tertulis (Amri \& Ahmadi, 2010, p. 159). Untuk menghasilkan suatu bahan ajar yang relevan dan mampu mengaktifkan siswa maka perlu adanya pengembangan bahan ajar. Harapannya dengan bahan ajar tersebut maka dapat menumbuhkan motivasi dalam dan menumbuhkan rasa ingin tahu dalam belajar.

Dalam penyusunan bahan ajar sebaiknya memperhatikan aspek seperti karakteristik siswa, karakeristik materi, lingkungan sekitar siswa. selain itu masing-masing siswa mempunyai karakteristik belajar yang berbeda. Sehingga dalam pengembangannya yang paling penting adalah kesesuaian dengan karakter pesera didik itu sendiri. Jika hal ini tidak diperhatikan, bahan ajar dapat menghambat proses pembelajaran itu sendiri (Uzuegbu et al., 2013, pp. 111120). Oleh karena itu diperlukan suatu analisis kebutuhan untuk mengidentifikasi masalah guna menentukan tindakan yang tepat. Hal ini dilakukan untuk mengurangi kesenjangan kebutuhan yang ada di lapangan.

Di sisi lain, di era modernisasi saat ini proses pembelajaran dengan berbasis multimedia merupakan salah satu bentuk upaya peningkatan kualitas pembelajaran. Keberadaan multimedia dalam proses pembelajaran dapat disusun dan diarahkan semenarik mungkin. Proses pembelajaran dengan berbasis multimedia merupakan salah satu bentuk upaya peningkatan kualitas pembelajaran, namun perlu diperhatikan keberadaan multimedia tentu harus menjadi fasilitas yang memudahkan siswa memahami materi, bukan justru menghambat 
pemahaman siswa terhadap materi yang dipelajari. Hal ini sesuai dengan pernyataan Kusumah (Paradesa, 2016) bahwa untuk meningkatkan kualitas pembelajaran, guru hendaknya memahami karakteristik berbagai media yang didukung teknologi, tahu cara menggunakannya, kelebihan dan kekuranganya.

Oleh karena itu, keberadaan multimedia sebagai penunjang efektifitas belajar perlu kualifikasi dan pengembangan yang signifikan sesuai kebutuhan dan pemanfaatan yang diperlukan. Multimedia adalah salah satu alternatif yang dapat meningkatkan pemahaman siswa serta dapat lebih menarik minat siswa untuk belajar. Multimedia mempunyai arti tidak hanya integrasi antara teks dan grafik sederhana saja tetapi dilengkapi dengan suara dan animasi. Jadi, sambil mendengarkan penjelasan, dapat melihat gambar, animasi maupun membaca penjelasan dalam bentuk teks.

Salah satu aplikasi multimedia yang dapat mendukung pengembangan bahan ajar di era moderniasi adalah aplikasi Macromedia Flash (Wicaksono \& Hakim, 2013). Aplikasi yang dapat digunakan dalam membuat media pembelajaran yang lebih menarik dan animatif (Durri et al., 2016). Hal ini sesuai dengan hasil penelitian Agus Ahmad Durri, Hendri Raharjo dan Arif Muchyidin (Durri et al., 2016) menunjukkan bahwa bahan ajar matematika berbasis multimedia flash bermuatan nilai-nilai Islam memiliki dampak positif terhadap respon peserta didikdan dapat meningkatkan hasil belajar siswa.

Adapun tujuan dari penelitian ini adalah untuk mengembangkan bahan ajar teori bilangan berbasis Macromedia Flash dan melihat kelayakannya serta bagaimana respon mahasiswa terhadap bahan ajar yang dikembangkan tersebut.

\section{Metode Penelitian}

Model pengembangan yang digunakan dalam penelitian ini adalah model pengembangan konseptual yakni model pengembangan yang bersifat analitis yang memberikan atau menjelaskan komponennya. Prosedur yang digunakan mengacu pada model pengembangan ADDIE (Analysis, Design, Development, Implementation and Evaluation). Desain validasi yang digunakan dalam penelitian pengembangan ini adalah validasi ahli materi dan dan validasi ahli desain/media. Obyek dari uji coba dalam penelitian ini yaitu mahasiswa jurusan PGMI konsentrasi matematika yang menempuh mata kuliah teori bilangan. Instrumen penilaian berupa angket skala Likert dengan memberikan tanda cek $(\sqrt{ })$ dengan alternatif jawaban Sangat Baik (5), Baik (4), Cukup (3), Kurang (2), Sangat Kurang (1). Instrumen penilaian ini untuk mengetahui dampak media ini terhadap minat siswa. Dilakukan uji coba pada kelompok kecil, 12 mahasiswa. Setelah itu dilakukan uji coba lapangan yang dilakukan kepada mahasiswa yang menempuh mata kuliah teori bilangan dan dipilih kelas konsentrasi matematika A sebanyak 32 mahaiswa. Uji coba ini dilakukan dengan tujuan untuk melihat respon mahasiswa terhadap pengembangan bahan ajar dengan menggunakan Macromedia Flash.

Teknik pengumpulan data dalam penelitian ini menggunakan angket untuk mengetahui penilaian ahli produk dan ahli isi pembelajaran, serta untuk melihat respon mahasiswa terhadap pengembangan bahan ajar teori bilangan berbasis Macromedia Flash. Teknik analisis yang digunakan dalam penelitian \& pengembangan ini yaitu teknik analisis isi dan teknik analisis deskriptif persentase. Teknik analisis isi digunakan untuk menganalisis data yang diperoleh 
dari tanggapan para konsultan ahli berupa catatan, saran, dan komentar yang terdapat dalam instrumen evaluasi fomatif. Sedangkan analisis deskriptif persentase digunakan untuk mengolah data yang didapat dari instrumen penilaian yang diberikan pada ahli materi dan ahli media/desain.

\section{Hasil dan Pembahasan}

Penelitian ini telah menghasilkan suatu produk berupa bahan ajar teori bilangan berbasis Macromedia Flash. Bahan ajar ini terdiri dari berbagai macam bentuk animasi, gambar, audio, dan teks. Bahan ajar teori bilangan ini ini dikembangkan dengan menggunakan aplikasi Macromedia Flash 8. Materi yang disajikan dalam bahan ajar ini yaitu Bilangan bulat dan operasinya (Sistem penjumlahan bilangan bulat, Sistem pengurangan bilangan bulat, Sistem perkalian bilangan bulat, Sistem pembagian bilangan bulat), Urutan Bilangan Bulat), Induksi Matematika, Konsep Keterbagian, FPB dan KPK, Konsep Dasar Kongruensi.

Penelitian pengembanngan ini menggunakan model pengembangan ADDIE (Analysis, Design, Development, Implementation, and Evaluation). Rancangan media pembelajaran yang dikembangkan dibagi menjadi beberapa bagian (scane), scanel (home), kurikulum/tujuan pembelajaran, bab dan sub bab, materi, isi, latihan soal dan dikemas dengan menggunakan Macromedia flash dalam bentuk flipping book yang bisa diakses secara online maupun offline.

Bahan ajar yang disusun sebagai produk awal setelah melalui tahapan analisis dan perencanaan, kemudian setelah itu dilanjutkan penilaian kepada pada ahli materi dan ahli media/desain untuk mendapatkan masukan dan saran. Dari saran dan masukan itu digunakan sebagai bahan perbaikan dan penyempurnaan media pembelajaran ini. Media pembelajaran hasil pengembangan ini mempunyai spesifikasi sebagai berikut:

1. Bahan ajar dibuat dengan menggunakan Macromedia Flash Professional 8 .

2. Memuat materi Bilangan bulat dan operasinya (Sistem penjumlahan bilangan bulat, Sistem pengurangan bilangan bulat, Sistem perkalian bilangan bulat, Sistem pembagian bilangan bulat), Urutan Bilangan Bulat), Induksi Matematika, Konsep Keterbagian, FPB dan KPK, Konsep Dasar Kongruensi.

3. Memuat latihan untuk simulasi mahasiswa

4. Bahan ajar dikemas dengan menggunakan flipping book sehingga bisa diakses secara online maupun offline.

Bahan ajar teori bilangan menggunakan macromedia flash professional 8 dikemas dengan flipping book dan dapat diakses secara online melalui alamat https://online.flippingbook.com/view/380 950/11/. Tampilan bahan ajar yang muncul dapat dilihat pada Gambar 1 sebagai berikut:

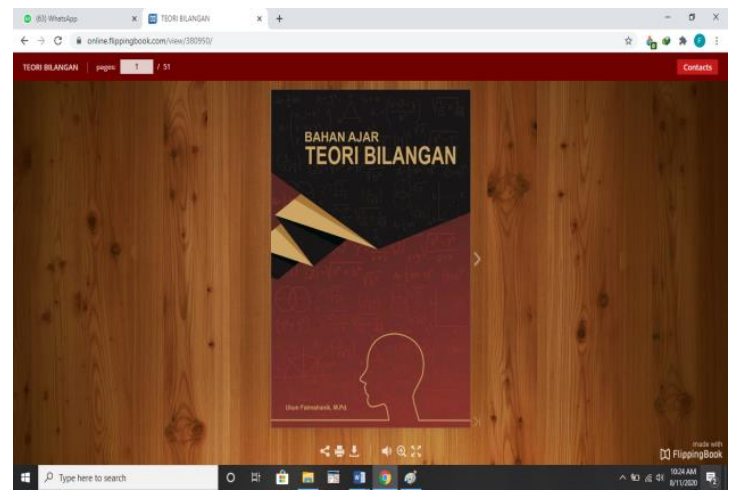

Gambar 1. Tampilan Cover Bahan Ajar Teori Bilangan

Selanjutnya setelah tampilan awal bahan ajar terdapat tampilan materi dan tampilan latihan soal yang dapat 
dilihat pada Gambar 2 dan 3 sebagai berikut:

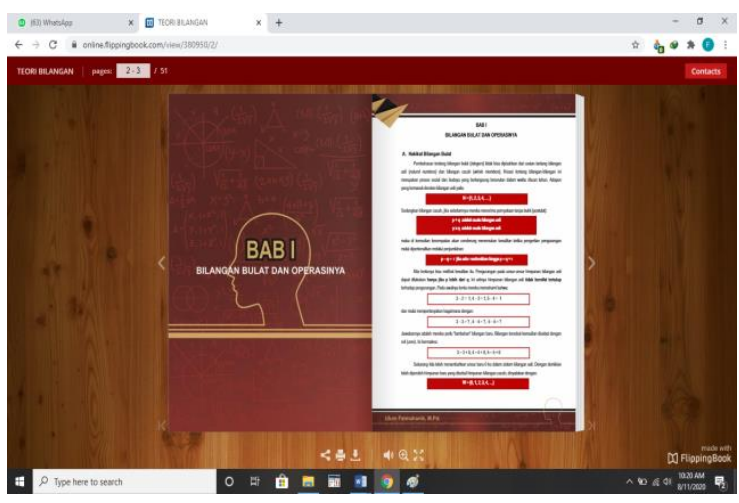

Gambar. 2 Tampilan Materi pada Bahan Ajar

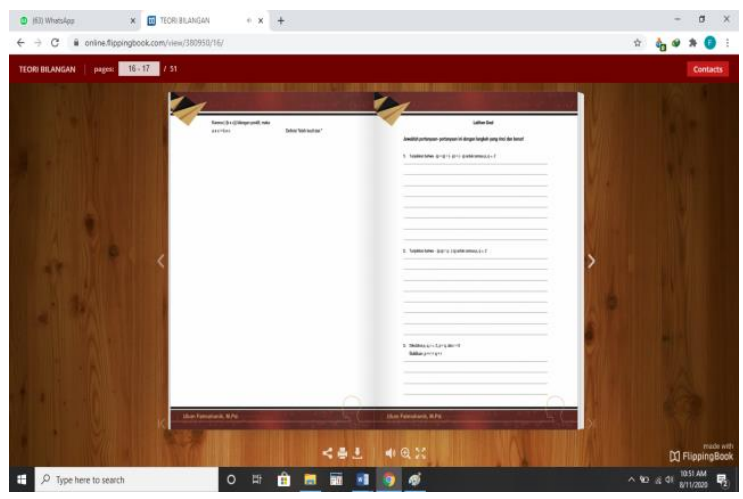

Gambar. 3 Tampilan Latihan Soal pada Bahan Ajar

Untuk mengetahui kualitas bahan ajar yang dikembangkan, maka perlu dilakukan penilaian oleh ahli materi oleh dosen pendidikan maematika, penilaian ahli media yang dilakukan oleh dosen pendidikan matematika yang mempunyai keahlian dalam bidak teknolog informasi. Kemudian penilaian juga dilakukan untuk mengetahui respon mahasiswa terhadap bahan ajar yang dikembangkan.

Berdasarkan teknik analisis data yang digunakan, maka data yang diperoleh dari penilaian para validator berupa data kualitatif diubah menjadi bentuk kuantitatif. Data kuantitatif yang dihasilkan kemudian ditabulasi dan dianalisis tiap aspek penilaian. Skor terakhir yang diperoleh, dikonversi menjadi tingkat kelayakan produk secara kualitatif dengan menggunakan kriteria kelayakan ideal. Adapun ringkasan hasil penilaian ahli materi dan ahli media dapat dilihat pada Gambar 4 sebagai berikut:

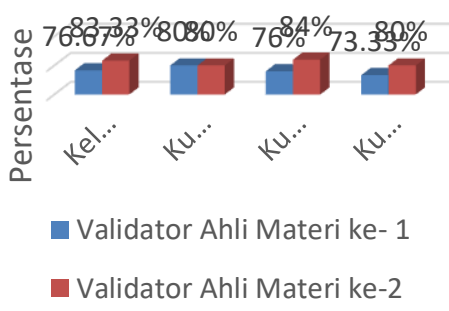

\section{Gambar 4. Grafik Hasil Penilaian Validator Ahli Materi Tiap Aspek}

Dari grafik tersebut dapat diketahui bahwa hasil penilaian ahli materi ke-1 dari aspek kelayakan isi yaitu $76,67 \%$ termasuk pada kategori cukup baik, hasil penilaian aspek kualitas pembelajaran $80 \%$ yang berarti berada pada kategori baik, presentase dari aspek kualitas penyajian/tampilan yaitu $76 \%$ yang menunjukkan kategori cukup baik, sedangkan dari aspek kualias interaksi menghasilkan $73,33 \%$ yang berarti bahwa bahan ajar ini dari segi kualitas interaksi berada pada kategori cukup baik. Sedangkan dari ahli materi ke-2 menunjukkan hasil penilaian $83,33 \%$ pada aspek kelayakan isi yang berarti berada pada kategori baik, $80 \%$ pada aspek kulitas pembelajaran, $84 \%$ pada aspek kualitas penyajian/tampilan dan $80 \%$ pada aspek interaksi yang ketiganya berada pada kategori baik.

Sedangkan rata-rata hasil penilaian ahli materi secara keseluruhan dapat dilihat pada Gambar 5 sebagai berikut: 


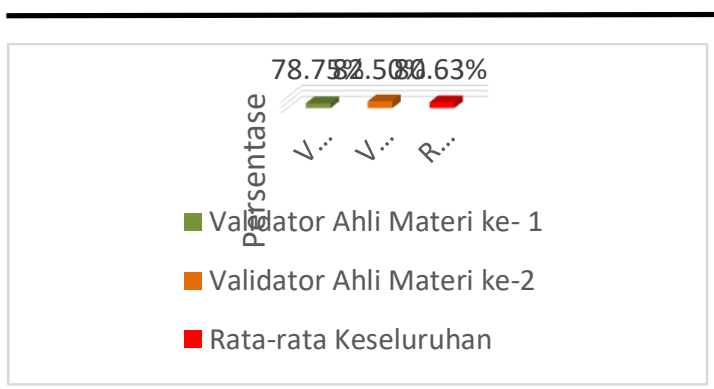

\section{Grafik 5. Grafik Rata-Rata Penilaian Validator Ahli Materi}

Berdasarkan Gambar 5 di atas dapat diketahui bahwa hasil validasi ahli materi bahan ajar teori bilangan berbasis Macromedia Flash oleh validator ahli materi yang pertama yaitu $78,75 \%$ atau berada pada kategori cukup baik. sedangkan hasil validasi oleh validator ahli materi yang kedua yaitu $82,50 \%$ yang berarti berada pada kategori baik. Secara keseluruhan hasil validasi ahli materi yaitu $80,63 \%$. Dari hasil tersebut menunjukkan bahwa hasil validasi tersebut berada pada kategori baik. Mekipun hasil dari validasi ini berkatergori baik namun saran dari ahli materi yaitu bahwa bahan ajar teori bilangan tersebut masih harus ditambah dengan tujuan pembelajaran. Sedangkan hasil penilaian ahli media dapat dilihat pada Gambar 6 sebagai berikut:

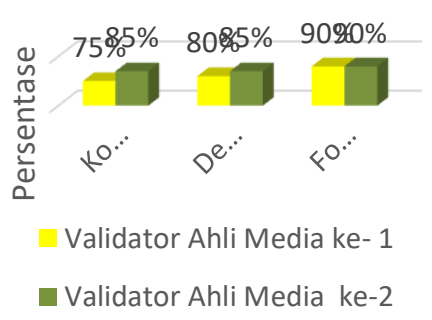

\section{Gambar 6. Grafik Rata-Rata Penilaian Ahli Media}

Dari Gambar 6 dapat diketahui bahwa hasil penilaian ahli media ke-1 dari aspek komunikasi yaitu 76,67\% termasuk pada kategori cukup baik, hasil penilaian aspek desain teknis $80 \%$ yang berarti berada pada kategori baik, dan presentase dari aspek format kemasan yaitu $90 \%$ yang menunjukkan kategori sangat baik. Sedangkan dari ahli media ke-2 menunjukkan hasil penilaian $85 \%$ pada aspek komunikasi yang berarti berada pada kategori baik, $85 \%$ pada desain teknis yang berarti berada pada kaegori baik dan $90 \%$ pada aspek format kemasan yang berarti berada pada kategori sangat baik.

Sedangkan rata-rata hasil penilaian ahli media secara keseluruhan dapat dilhat pada Gambar 7 sebagai berikut:

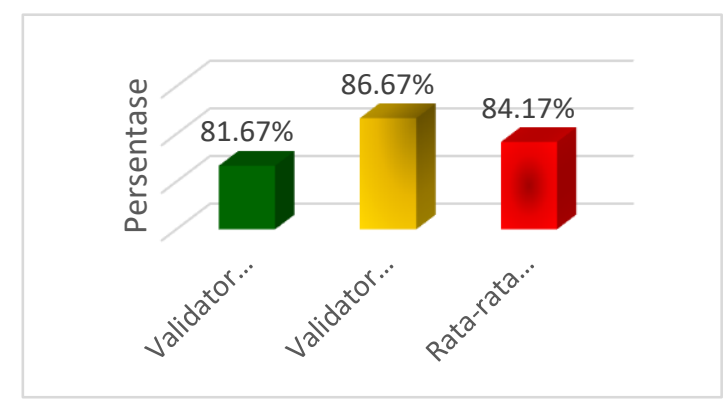

Gambar 7. Grafik Rata-Rata Penilaian Ahli Media

Berdasarkan Gambar 7 dapat diketahui bahwa hasil validasi desain media bahan ajar teori bilangan berbasis Macromedia Flash oleh validator ahli media yang pertama yaitu $81,43 \%$. Hal ini menunjukkan bahwa dari segi media bahan ajar berada pada kategori baik. Sedangkan hasil penilaian oleh validator ahli media yang kedua yaitu $87,14 \%$, yang berarti bahan ajar yang dikembangkan dari segi media berada pada kategori baik. Secara keseluruhan bahan ajar teori bilangan berbasis Macromedia Flash ini mempunyai nilai rata-rata $84,285 \%$. Hal ini menunjukkan bahwa bahan ajar sudah baik dan tidak perlu ada revisi.

Setelah melalui tahap penilaian ahli materi dan ahli media maka bahan ajar diujicobaan kepada mahasiswa. Adapun hasil respon mahasiswa terhadap bahan ajar teori bilangan berbasis 
Macromedia Flash dapat dilihat pada Gambar 8 sebagai berikut:

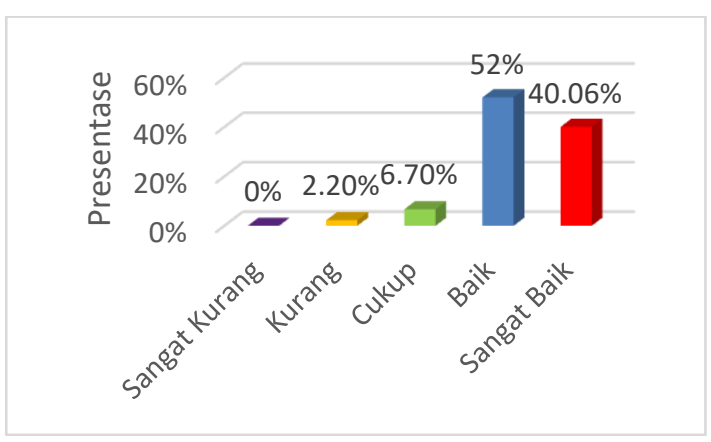

\section{Gambar 8. Grafik Rata-Rata Hasil Respon Mahasiswa terhadap Bahan Ajar Teori Bilangan}

Pada Gambar 8 menunjukkan bahwa rata-rata hasil respon mahasiswa terhadap bahan ajar teori bilangan berbasis Macromedia Flash menyatakan $2,2 \%$ kurang baik, 6,7\% mahasiswa menyatakan cukup, 52\% mahasiswa menyatakan cukup baik dan 40,06\% menyatakan bahwa bahan ajar teori bilangan berbasis Macromedia Flash sangat baik.

\section{Kesimpulan}

Dari hasil pengembangan menunjukkan bahwa bahan ajar teori bilangan berbasis Macromedia Flash layak untuk digunakan dalam pembelajaran teori bilangan yang ditunjukkan dari hasil penilaian ahli materi $80,63 \%$ yang berarti bahan ajar yang dikembangkan mempunyai kualitas baik. Hasil penilaian ahli media menunjukkan bahwa bahan ajar teori bilangan berbasis macromedia flash mempunyai kualitas baik dengan diperoleh skor $84,17 \%$. Sedangkan respon mahasiswa $52 \%$ menyatakan baik dan $40,06 \%$ mahasiswa menyatakan sangat baik.

Berdasarkan penilaian tersebut dapat disimpulkan bahwa bahan ajar teori bilangan berbasis Macromedia Flash layak digunakan sebagai sumber belajar mandiri dalam pembelajaran teori bilangan. Harapannya dengan pengembangan bahan ajar ini pembelajaran dapat berlangsung dengan aktif, kreatif dan menyenangkan.

\section{Referensi}

Amri, S., \& Ahmadi, I. K. 2010. Konstruksi pengembangan pembelajaran. Jakarta: Prestasi Pustaka.

Dubin, F., Eskey, D. E., Grabe, W., \& Savignon, S. 1986. Teaching second language reading for academic purposes. AddisonWesley Reading, MA.

Durri, A. A., Raharjo, H., \& Muchyidin, A. 2016. Applications of Mathematics Charged Islamic Values by Using Macromedia Flash and Camtasia. ITEj (Information Technology Engineering Journals), 1(1).

Iji, C. O., Ogbole, P. O., \& Uka, N. K. 2014. Effect of improvised instructional materials on students achievement in Geometry at the Upper Basic Education Level in Makurdi Metropolis, Benue State, Nigeria. Educational Research and Reviews, 9(15), 504-509.

Mahardika, I. K. 2011. Pengembangan Bahan Ajar Mekanika untuk Meningkatkan Kemampuan Representasi Verbal, Matematis, Gambar, dan Grafik Mahasiswa Calon Guru Fisika [PhD Thesis]. Universitas Pendidikan Indonesia.

Nwike, M. C., \& Catherine, O. 2013. Effects of use of instructional materials on students cognitive achievement in agricultural science. Journal of Educational and Social Research, 3(5), 103. 
Paradesa, R. 2016. Pengembangan Bahan Ajar Geometri Transformasi Berbasis Visual. Jurnal Pendidikan Matematika RAFA, 2(1), 56-84.

Shodikin, A. 2017. Pengembangan Bahan Ajar Kalkulus Integral Berbasis Animasi. Aksioma: Jurnal Program Studi Pendidikan Matematika, 6(1), 1-11.

Uzuegbu, C. P., Mbadiwe, H. C., \& Anulobi, J. C. 2013. Availability and utilization of instructional materials in teaching and learning of library education in tertiary institutions in Abia state. Wudpecker Journal of Educational Research, 2(8), 111120.
Wicaksono, D. S., \& Hakim, F. N. 2013. Media Pembelajaran Fisika Interaktiv Bahasan Kapasitor Berbasis Flash Dan XML. SpeedSentra Penelitian Engineering Dan Edukasi, 3(2).

Zakiyah, M. 2012. Pengembangan Bahan Ajar Pendidikan Berpikir Kritis Melalui Pembelajaran Menulis Karya Ilmiah di SMA/MA Kelas XI. SKRIPSI Jurusan Sastra Indonesia-Fakultas Sastra UM. 